\title{
PENGARUH DIMENSI FURNITUR TERHADAP TERITORI PERSONAL PENGATURAN MEJA MAKAN DENGAN SISTEM MAKAN BERBAGI PADA RESTORAN
}

\author{
Erlana Adli Wismoyo ${ }^{(1) *}$, Ummu Havizahra ${ }^{(2)}$ \\ (1)(2) Program Studi Desain Interior \\ Universitas Telkom Bandung \\ Submitted : 25 January 2021 \\ erlanadliw@telkomuniversity.ac.id,ummuhavizahra@student.telkomuniversity.ac.id \\ Submitted : 19 August $2020 \quad$ Revised: 25 February 2020 \\ Accepted : 3 March 2021
}

\begin{abstract}
ABSTRAK
Tujuan dari penelitian ini adalah untuk mengetahui teritori personal yang sesuai dengan kebutuhan aktivitas pada area makan. Area makan, merupakan hal yang paling utama pada suatu restoran yang menentukan pengalaman ruang bagi penggunanya, untuk itu kenyamanan ketika aktivitas di meja makan perlu diperhatikan. Setiap restoran menerapkan sistem makan yang berbeda, salah satunya adalah sistem makan berbagi, yaitu beberapa menu hidangan yang dinikmati lebih dari satu orang. Sistem ini tentunya mempengaruhi dimensi meja makan yang digunakan dan teritori personal area makan seorang pengunjung dalam aktivitas makan-minumnya. Analisis data diolah secara deskriptif dengan data kualitatif yang diperoleh dari observasi langsung pada restoran yang memiliki sistem makan berbagi, yakni restoran Al-Jazeerah dan Miss Bee Providore yang berlokasi di kota Bandung. Hasil dari penelitian ini menunjukan bahwa kebutuhan teritori personal pada suatu restoran dapat berbeda sesuai bentuk dan ukuran peralatan makan dari menu hidangan yang disediakan.
\end{abstract}

Kata Kunci: Meja Makan, Restoran, Teritori Personal

\section{THE EFFECT OF FURNITURE DIMENSION FOR PERSONAL TERRITORY TABLE SETTING WITH SHARING SYSTEM IN THE RESTAURANT}

\section{ABSTRACT}

The purpose of this research is to find out personal territory that suitable for the activity in the dining area. Restaurant is one of the sector in the hospitality industry, an intresting destination for the general public and tourists to enjoy many various of culinary both food and drinks. Dining area is the most important thing in the restaurant that determines the experience of space for the users, so customer comfortable when doing activities at the dining table need to be considered. Every restaurant uses a different dining system, one of them is food sharing system, which is a dish that are eaten by more than one person. This system affects the dimensions of the dining table and the territories of customer private areas in their eating and drinking activities. Data analysis was processed descriptively with qualitative data obtained 
Erlana Adli Wismoyo, Ummu Havizahra: Pengaruh Dimensi Furnitur Terhadap Teritori

Personal Pengaturan Meja Makan dengan Sistem Makan Berbagi pada Restoran

from direct observation on restaurants that have shared dining systems, that is AlJazeerah and Miss Bee Providore restaurants located in Bandung. Results of this study indicate that the needs of personal territory in a restaurant can be different according to the shape and size of cutlery from the menu of dishes.

\section{Keywords: Dining Table, Personal Teritory, Restaurant}

\section{PENDAHULUAN}

Hutama \& Subagio (2014) menyatakan bahwa pengalaman bersantap meliputi tiga aspek, yaitu food quality, service quality, and physical environment. Penelitian ini dilakukan untuk melihat ruang gerak pengunjung di restoran di dalam teritori personalnya yang berkorelasi dengan pengalaman bersantap tersebut. Salah satu industry hospitality untuk melaksanakan food service industry adalah restoran. Hal paling penting dalam suatu restoran adalah menu hidangannya (Rahayu dkk, 2016). Hidangan menjadi ciri dari gaya memasak dan tradisi terkait dengan budaya tertentu pada suatu restoran yang akan menentukan penyesuaian aspek-aspek lainnya.

Dalam penelitian ini dilakukan observasi terhadap restoran, yakni AlJazeerah Signature yang menyajikan hidangan Timur Tengah dan Miss Bee Providore yang menyajikan hidangan Italia. Ciri pelayanan dan sistem penyajian disesuaikan dengan jenis dan konsep restoran (Hidayat \& Setiawan, 2015). Salah satu sistem penyajian hidangan pada restoran adalah sistem makan berbagi/sharing, yaitu menu hidangan yang dinikmati lebih dari satu orang secara bersamaan. Sistem ini tentunya mempengaruhi dimensi meja makan yang digunakan dan teritori personal area makan seorang pengunjung dalam aktivitas makan-minumnya dan aktivitas lain (Sari, 2009). Satu kursi dan sebagian dari meja merupakan satu area teritori untuk aktivitas makan-minum dari satu pengunjung restoran. Oleh karena itu teritori personal pengunjung pada area makan restoran menjadi salah satu faktor pengalaman ruang (Wardiyanta dkk, 2020) yang akan dirasakan oleh pengunjung restoran secara langsung, apakah sesuai atau tidak.

Buku Human Dimension dan buku Data Arsitek digunakan sebagai acuan perencanaan pengaturan meja dan kursi pada area makan di restoran agar sesuai dengan dimensi manusia yang akan diperuntukkan untuk area makan. Acuan lain terkait teritori pengguna ruang makan pada restoran tersebut adalah teori privasi dan ruang personal yang dibahas oleh Hall (1990). Hall membahas mengenai area personal manusia terhadap lingkungannya. Dimana pada dasarnya manusia memiliki area privasi yang dapat terhitung, sehingga manusia memiliki teritori yang bisa terganggu oleh manusia lain jika teritori tersebut dimasuki oleh manusia lain.

Penelitian ini berupaya untuk menjawab permasalahan teritori personal ketika aktivitas makan-minum pengunjung di restoran dengan table setting hidangan sharing dan untuk menjawab hubungan antara dimensi meja makan dengan teritori personal manusia. Metode penelitian yang akan digunakan dalam penelitian ini bersifat kualitatif dan disampaikan secara deskriptif.

\section{TINJAUAN PUSTAKA Restoran}

Menurut Suyono (2004), restoran adalah tempat yang berfungsi untuk menyegarkan kembali kondisi seseorang dengan menyediakan kemudahan makan dan minum. Menurut Atmodjo, dan Marsum (2005), restoran adalah suatu tempat atau bangunan yang diorganisir secara komersil yang menyelenggarakan pelayanan dengan baik kepada semua konsumen baik berupa makanan maupun 
minuman. Dapat disimpulkan restoran adalah tempat untuk menjual makanan dan minuman yang mengutamakan fasilitas serta pelayanan yang ramah sebagai nilai jualnya.

\section{Hidangan Timur Tengah}

Heine (2018) dalam buku The Culinary Crescent: A History of Middle Eastern Cuisine menyebutkan, etos makan secara komunal terekspresikan pada tradisi lain, satu kisah Nabi yang menunjukkan sikap makan bersama dengan hanya mengambil makanan pada sisi tepi piring hidangannya, agar sahabat-sahabat dapat mengambil hidangan pada tiap sisi lainnya.

Hidangan sharing yang paling umum disajikan pada restoran bergaya Timur Tengah, yaitu nasi kebuli dan daging kambing sebagai menu utama (main course) yang ditawarkan. Mirip dengan budaya Asia, ternyata masyarakat Timur Tengah juga lebih menyukai tradisi makan bersama. Sementara untuk tipe makanan sama seperti budaya Bara, yaitu terdiri dari hidangan pembuka, makanan utama, dan hidangan penutup. Pembedanya adalah cara dan waktu penyajiannya. Dalam budaya bersantap masyarakat Western, ketiga jenis makanan ini seringkali disuguhkan bertahap dalam beberapa waktu. Misalnya, makanan pembuka disajikan lebih dulu, kemudian dilanjutkan makanan utama dan terakhir hidangan pencuci mulut. Sedangkan budaya makan di Timur Tengah, ketiga jenis makanan disuguhkan sekaligus dalam satu kali penyuguhan. Tata cara makan Timur Tengah biasanya akan makan secara lesehan di atas karpet dan di sebuah meja yang panjang (Yahya, 2019). Kemudian memakan nasi dan lauk dalam satu wadah besar secara bersama-sama dengan menggunakan tangan.

Masyarakat Timur Tengah gemar makan sambil mengobrol untuk menjalin keakraban biarpun makanan telah habis mereka akan tetap mengobrol. Seiring dengan globalisasi dan modernisasi kebanyakan negara kini telah menggunakan tata cara makan yang modern diatas meja makan dengan menggunakan sendok, garpu, pisau, dan lainnya. Hal ini pula yang diterapkan oleh kebanyakan restoran bergaya Timur Tengah saat ini.

\section{Hidangan Italia}

Capatti (2003) dalam buku Italian Cuisine: A Cultural History menyatakan, Francesco Leonardi yang lahir di Roma merupakan salah satu chef otentik Italia yang berjasa untuk menaikkan hidangan Italia menjadi hidangan Internasional. Bagi banyak orang di seluruh dunia, masakan Italia yang umum dikenal adalah pizza, spaghetti, ravioli, lasagna, parmigianoreggiano, dan minestrone.

Penyajian hidangan tradisonal Italia terdiri dari empat jenis, yaitu Primo, Secondo, Contorno dan Digestivo. Primo adalah makanan yang dihidangkan bersama makanan lain, Secondo berarti makanan utama, Contorno berarti makanan tambahan, dan Digestivo berarti makanan penutup. Melihat keempat jenis tersebut, wajar jika orang Italia menghabiskan banyak waktu di meja makan.

\section{Aktivitas pada Meja Makan Restoran}

Menurut Mulyono (2001;26) Aktivitas artinya kegiatan atau keaktifan. Jadi segala sesuatu yang dilakukan atau kegiatankegiatan yang terjadi baik fisik maupun non-fisik, merupakan suatu aktivitas. Berikut beberapa aktivitas pengunjung yang membentuk pola perilaku di restoran khususnya pada area meja makan:

1. Memesan makanan

2. Makan-minum

3. Menyiapkan dan menyajikan hidangan

4. Berbincang-bincang

5. Meeting

6. Bermain handphone/laptop

7. Fotografi 
Erlana Adli Wiswoyo, Ummu Havizahra: Pengaruh Dimensi Furnitur Terhadap Teritori Personal Pengaturan Meja Makan dengan Sistem Berbagi pada Restoran

\section{Teritori Personal/Personal Space}

Browner dalam Nur'aini (2019) menyatakan bahwa teritorialitas merupakan aspek khusus perilaku spasial yang pertama kali digunakan dalam hubungan perilaku spasial hewan. Perilaku teritorial mempersempit ruang untuk menciptakan lingkungan yang dapat diprediksi dengan rasa dan keamanan yang dialaminya. Konsep mengenai personal space tidak hanya ada di psikologi namun juga dijelaskan di ilmu biologi, antropologi dan arsitektur. Kita mempertahankan personal space antara diri kita dengan orang lain untuk menghindari stimulasi yang berlebihan menurut subjektifitas masing-masing (Nizar \& Setyowati, 2021). Scott dalam Halim (2005) menyatakan bahwa terlalu dekat jarak kita dengan orang lain akan menyebabkan kita terlalu banyak dihujani oleh stimulan sosial ataupun fisikal. Kita mempertahankan personal space untuk menghindari berbagai macam penyebab stres yang diasosiasikan dengan jarak yang terlalu dekat.

Teori behavior-constraint menyarankan personal space seseorang harus dijaga untuk mencegah kebebasan perilaku seseorang yang terlalu dekat dengan kita. Seorang antropolog Edward dalam Halim (2005) mengkonsepkan personal space sebagai bentuk dari komunikasi nonverbal. Menurutnya jarak antar individu menentukan kualitas dan kuantitas stimulasi yang dipertukarkan. Jarak tersebut juga menentukan jenis hubungan antar individu dan jenis aktivitas yang dilakukan. Lang dalam Ishak (2018) menyatkan, karakter dari teritorialitas tersebut adalah sebagai berikut:

1. Kepemilikan atau hak atas suatu tempat

2. Penandaan dari suatu area tertentu

3. Hak untuk mempertahankan diri dari gangguan luar

4. Pengatur dari berbagai fungsi, mulai dari bertemunya kebutuhan dasar psikologis sampai kepada kepuasan kognitif, dan kebutuhan-kebutuhan estetika.

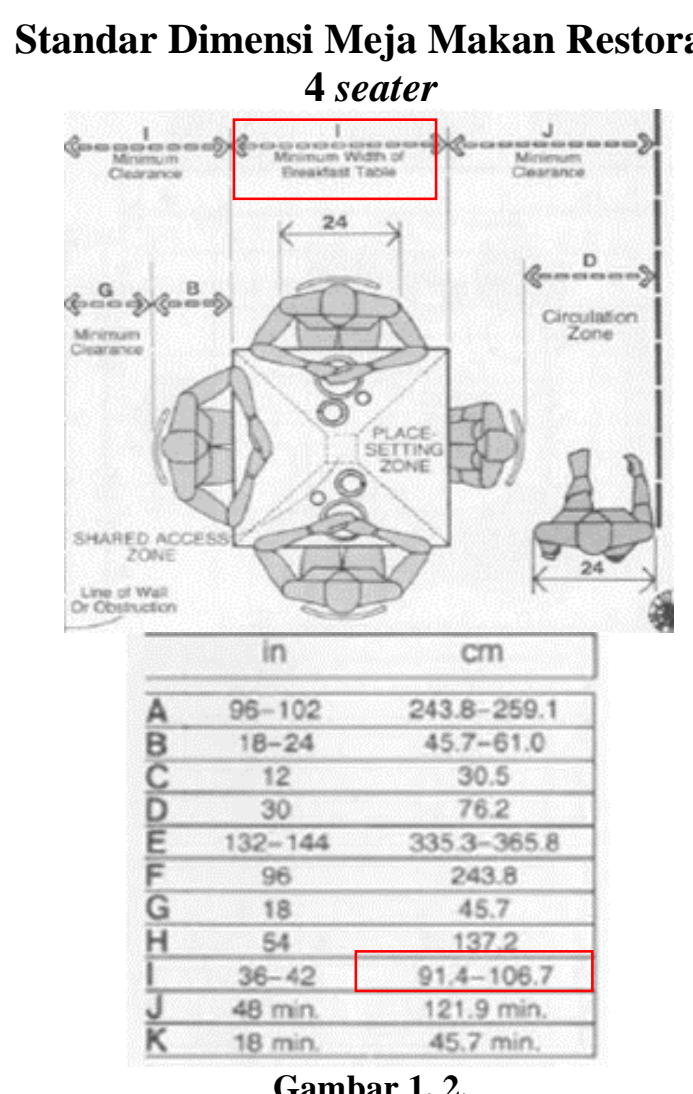

Standar Dimensi Meja Makan 4 Seater sumber: Buku Human Dimension

Menurut Panero dan Zelnik (1979) dalam buku Human Dimension teritori personal/ruang personal yang standar ketika makan bersama (empat seater), yaitu 91,4-121,9 cm. Area dengan ukuran tersebut memungkinkan bagi seseorang bergerak dengan efektif.

\section{Standar Dimensi Meja Makan Restoran}

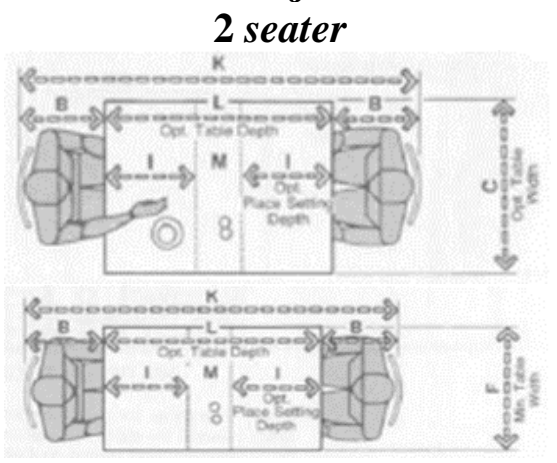




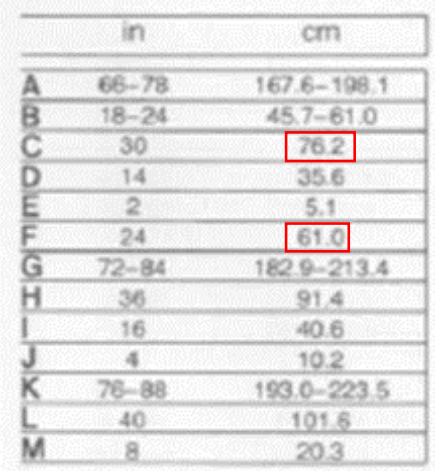

Gambar 3, 4, 5 . Standar Dimensi Meja Makan 2 Seater Minimum dan Optimum sumber: Buku Human Dimension

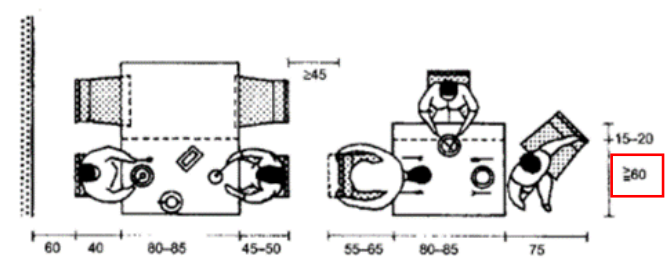

Gambar 6. Standar Teritori Meja Makan Lebih Dari 1 orang

sumber: Buku Data Arsitek

Lalu, dimensi standar teritori personal pada meja makan dua seater minimumnya adalah $61,0 \mathrm{~cm}$ dan optimumnya adalah $76,2 \mathrm{~cm}$, sedangkan menurut Neufert (2019) pada buku Data Arsitek, teritori personal yang standard, yaitu $\pm 60 \mathrm{~cm}$. Area dengan ukuran tersebut memungkinkan bagi seseorang bergerak dengan efektif baik itu aktivitas makan, minum maupun aktivitas lainnya diatas meja.

\section{METODE PENELITIAN}

Metode yang digunakan dalam penelitian ini adalah metode penelitian yang bersifat deskriptif dengan data kualitatif, dimana metode ini digunakan dalam analisa dan observasi untuk mengetahui permasalahan terkait teritori personal aktivitas makan-minum ketika makan dengan sistem sharing.

Penelitian dilakukan dengan melakukan observasi langsung di restoran Al-Jazeerah dan Miss Bee Providore yang ada di kota Bandung terkait teritori personal ketika aktivitas makan-minum pengunjung yang berhubungan dengan table setting, sistem pelayanan, serta jenis, bentuk, dan dimensi meja makan akan diperhatikan. Hal tersebut akan menjadi dasar untuk analisa dan menjawab permasalahan terkait teritori personal ketika makan dengan sistem berbagi/sharing.

\section{HASIL DAN PEMBAHASAN Hubungan Teritori Personal dengan Area Makan.}

Teritori personal area makan pada suatu restoran perlu diperhatikan untuk menciptakan ruang privasi dan pengalaman ruang yang baik pada saat aktivitas makanminum. Dalam hal ini, peneliti melakukan penelitian dengan cara observasi langsung dan analisa pada beberapa restoran yang menyajikan hidangan sharing pada menunya, yaitu restoran Al-Jazeerah dan Miss Bee Providore yang akan menjadi bahasan pada penelitian kali ini.

\section{a. Restoran Al-Jazeerah}

Restoran Al-Jazeerah merupakan specialty restaurant yang mengusung konsep Timur Menu dan Sistem penyajian makanan pada restoran Al-Jazeerah menyesuaikan konsep penyajian makanan Timur Tengah, yakni dengan sistem sharing (berbagi) atau porsi makanan yang besar untuk dinikmati sekaligus oleh banyak orang. Restoran Al-Jazeerah juga menyediakan penyajian hidangan lainnya pada ruangan makan lesehan dengan privasi yang terjaga yang juga merupakan ciri khas Timur Tengah.

\section{Area makan}

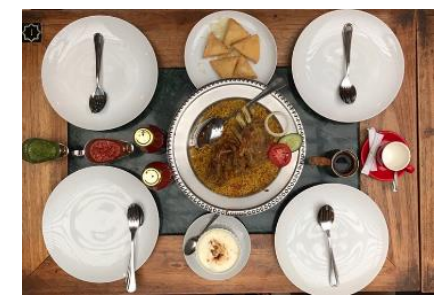

Gambar 7. Penataan Settingan Makan Tengah Hidangan Sharing (Al-Jazeerah) sumber : Dokumentasi peneliti 2020

Observasi langsung dilakukan peneliti 
Erlana Adli Wiswoyo, Ummu Havizahra: Pengaruh Dimensi Furnitur Terhadap Teritori Personal Pengaturan Meja Makan dengan Sistem Berbagi pada Restoran

dengan memesan hidangan lengkap, yaitu (Main Course, Appetizer, Dessert, dan Beverage) yang merupakan sharing item dari restoran Al-Jazeerah.

Hidangan tersebut disusun pada meja makan ukuran 70x100 cm, dimana meja tersebut seharusnya adalah meja makan untuk dua seater. Peneliti mencoba memaksimalkan area meja makan sehingga semua hidangan dapat disajikan pada meja tersebut.

\section{Table Setting}

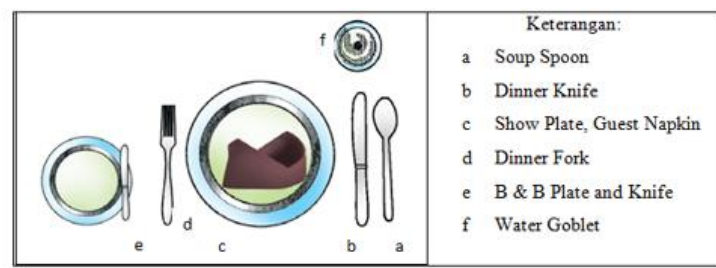

Gambar 8. Standart Table Setting

Sumber: Food \& Beverage Table Setting

Pada saat pengunjung datang, penataan table setting pada restoran Al-Jazeerah adalah standart table setting. Standar table setting sendiri berarti table set-up yang digunakan untuk meja makan pagi (breakfast) dan makan siang dan malam (lunch and dinner).
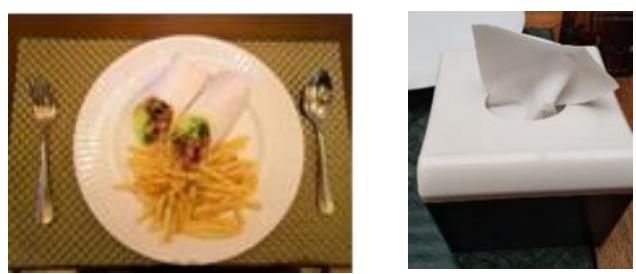

Gambar 9.

Penataan Table Setting

Restoran Al-Jazeerah

sumber: Dokumentasi peneliti 2020

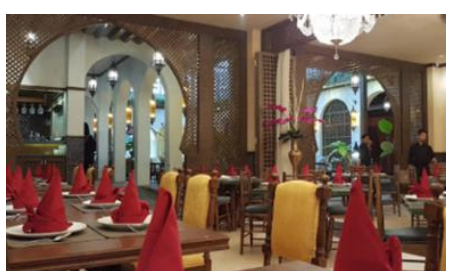

Gambar 11. Table Setting pada Restoran Al-Jazeerah

sumber: Dokumentasi peneliti 2020

Dapat dilihat standart table setting pada restoran Al-Jazeerah terdiri dari piring, sendok, garpu, pisau makan, lap, dan tempat tisu pada setiap meja makannya, terdapat juga nomor meja berupa stiker di ujung setiap meja.

\section{Menu Hidangan Sharing}

Tabel berikut merupakan daftar beberapa menu hidangan sharing yang ada pada restoran Al-Jazeerah dan menjadi dasar untuk menganalisa teritori personal ketika penataan meja makan dengan pusat hidangan berada di tengah.

Tabel 1. Menu Hidangan Sharing pada Restoran Al-Jazeerah Signature

\begin{tabular}{|c|c|c|c|c|}
\hline No & Nama Menu & Dimensi & Dokumentasi & Analisa \\
\hline 1. & $\begin{array}{l}\text { Samosa } \\
\text { (Appetizer- } \\
\text { Sharing Item) }\end{array}$ & $\varnothing 25 \mathrm{~cm}$ & & $\begin{array}{l}\text { Disajikan dengan pelengkap berupa saus sambal } \\
\text { dan saus tomat. Area yang terpakai tidak besar, } \\
\text { masih dapat membuat efektif sirkulasi di meja. }\end{array}$ \\
\hline 2. & Salad & $\emptyset 20 \mathrm{~cm}$ & & $\begin{array}{l}\text { Disajikan sudah dicampur antara komponen } \\
\text { dengan driessng. Area yang terpakai tidak besar } \\
\text { masih dapat membuat efektif sirkulasi di meja. }\end{array}$ \\
\hline 3. & Soup & $\varnothing 15 \mathrm{~cm}$ & & $\begin{array}{l}\text { Dihidangkan dengan satu buah rot } \\
\text { bawang/garlic bread sebagai pelengkap. Area } \\
\text { yang terpakai tidak besar, masih dapat membuat } \\
\text { efektif sirkulasi di meja. }\end{array}$ \\
\hline
\end{tabular}


Erlana Adli Wismoyo, Ummu Havizahra: Pengaruh Dimensi Furnitur Terhadap Teritori Personal Pengaturan Meja Makan dengan Sistem Makan Berbagi pada Restoran

\begin{tabular}{|c|c|c|c|}
\hline 4. & $\begin{array}{l}\text { Lamb Kabsah } \\
\text { (Main Course- } \\
\text { Sharing Item) }\end{array}$ & $\varnothing 35 \mathrm{~cm}$ & $\begin{array}{l}\text { Dihidangkan dengan pelengkap sambal merah } \\
\text { dan hijau ala Timur Tengah sebagai penyegar } \\
\text { karena yang kami pesan adalah large size area } \\
\text { yang terpakai cukup banyak ditengah meja } \\
\text { namun luasan di meja masih dapat dibilang } \\
\text { efektif. }\end{array}$ \\
\hline 5. & $\begin{array}{l}\text { Umm Ali } \\
\text { (Dessert) }\end{array}$ & $\varnothing 15 \mathrm{~cm}$ & $\begin{array}{l}\text { Penyajian dessert dilengkapi dengan sendok } \\
\text { khusus untuk memakannya. Area yang terpakai } \\
\text { tidak besar, masih dapat membuat efektif } \\
\text { sirkulasi dimeja. }\end{array}$ \\
\hline 6. & $\begin{array}{c}\text { Arabic Tea } \\
(\text { Sharing Item })\end{array}$ & $\varnothing 10 \mathrm{~cm}$ & $\begin{array}{l}\text { Penyajian Arabic Tea cawan beserta gelas. Area } \\
\text { yang digunakan cukup besar. }\end{array}$ \\
\hline 7. & Turkish Coffee & $\varnothing 7 \mathrm{~cm}$ & $\begin{array}{l}\text { Penyajian minuman (kopi turki): sari kopi } \\
\text { dihidangkan pada cawan terpisah dengan gelas, } \\
\text { diberi gula sachet dua bungkus untuk dituangkan } \\
\text { sesuai selera konsumen. Area yang digunakan } \\
\text { hanyalah sedikit sehingga area tersisa masih } \\
\text { dapat digunakan untuk barang bawaan } \\
\text { pengunjung, seperti dompet, hp atau kamera } \\
\text { masih bisa diletakan di meja. }\end{array}$ \\
\hline
\end{tabular}

Sumber : Olahan Peneliti 2020

Berdasarkan pemesanan ketika observasi, terdapat lima menu yang dipesan pada restoran Al-Jazeerah, yaitu 2 menu sharing (Lamb Kabsah, Samosa), 3 menu personal (Salad, Soup, Umm Ali), 1 minuman sharing (Arabic Tea), dan 1 minuman personal (Turkish Coffee). Dapat dilihat restoran Al-Jazeerah menyediakan hidangan sharing dan penyajian hidangan menjadi settingan makan tengah.

\section{Simulasi}

Untuk memperjelas hasil analisa yang dilakukan ketika observasi langsung, berikut simulasi penataan dan simulasi teritori yang didapat:

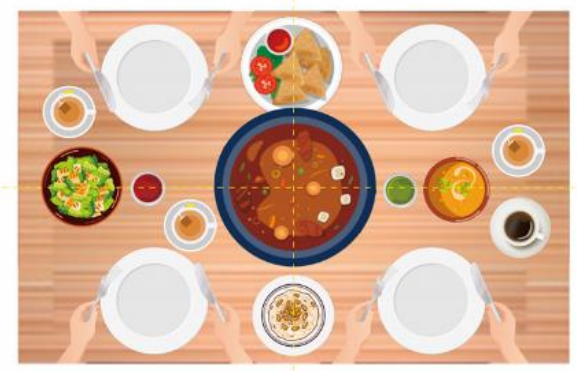

Gambar 13. Simulasi Akhir Teritori Makan ketika Observasi Langsung

sumber: Hasil pengolahan data 2020

Pada meja makan dengan dimensi 70x100 cm disusun seluruh hidangan yang dipesan. Hidangan disajikan membentuk persegi dengan konsumen yang saling berhadap-hadapan. Sebagai berikut:

1. Hidangan utama di tengah meja makan.

2. Pengambilan hidangan sharing dilakukan secara bergantian.

3. Siku bertabrakan ketika makan dan kesulitan saat mengambil menu utama secara bersamaan.

\section{Penyesuaian Dimensi Furnitur/meja makan}

Meja ketika observasi langsung seharusnya adalah meja makan untuk dua seater. Peneliti memaksimalkan teritori yang tersedia untuk memuat semua menu hidangan yang dipesan ke dalam satu meja. Meja yang seharusnya untuk dua seater dijadikan empat seater karena dirasa luasan masih mencukupi. Kemudian dibuat 
simulasi aktivitas makan dengan table setting membentuk plus. Hal ini membuat teritori personal jauh lebih luas, pergerakan menjadi lebih mudah karena lengan tidak bertabrakan dengan siku orang yang ada di sebelahnya.

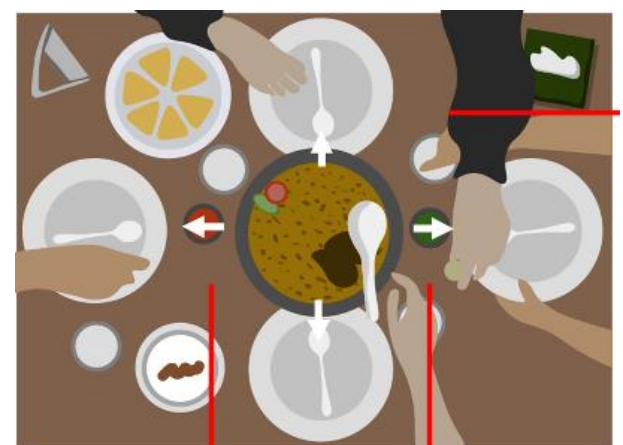

Gambar 14. Ilustrasi Penyesuaian Teritori Settingan Makan Tengah sumber: Hasil pengolahan data 2020

Dari simulasi diatas, hidangan utama diletakan di tengah meja makan sehingga posisi pengambilan makanan ke depan mengarah ke hidangan utama sharing.

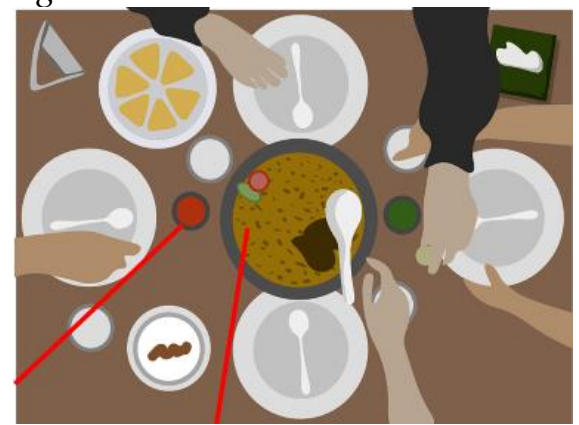

Gambar 15. Ilustrasi Penyesuaian Teritori Settingan Makan Tengah sumber: Hasil pengolahan data 2020

Dari ilustrasi tersebut dapat diketahui bahwa area yang diberi tanda tersebut merupakan area teritori yang dimiliki bersama oleh orang yang berdekatan.

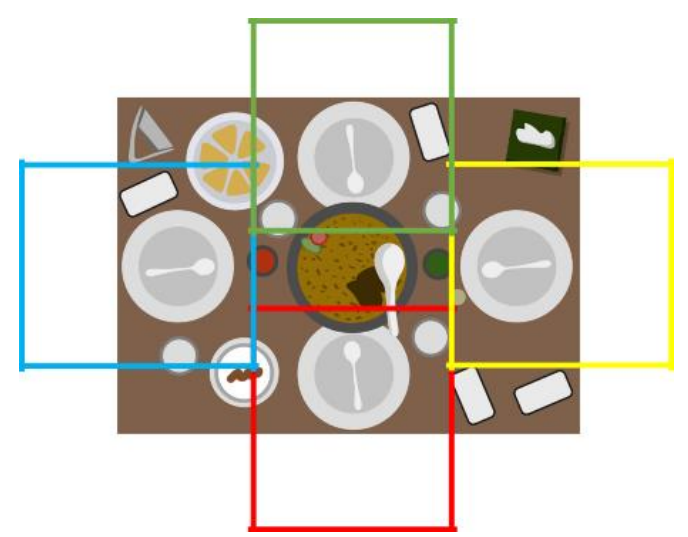

Gambar 16. Ilustrasi Teritori Settingan Makan Tengah untuk Setiap Orang sumber: Hasil pengolahan data 2020

Berdasarkan penyesuain tersebut teritori personal yang didapat adalah $50 \times 60 \mathrm{~cm}$ untuk setiap orangnya, teritori tersebut membuat area siku yang terbuka sehingga tidak terjadi siku yang bertabrakan.

\section{Hasil Analisis}

Setelah mempelajari dimensi standar teritori personal meja makan untuk empat seater dari buku Human Dimension dan menganalisis dimensi meja makan yang digunakan ketika observasi langsung, peneliti kemudian melakukan simulasi penyesuaian teritori personal yang lebih baik, hal ini menyebabkan luasan dimensi teritori personal yang berbeda.

Oleh karena itu, peneliti mencoba membandingkan standar dari buku Human Dimension dengan hasil analisis terhadap salah satu dimensi meja makan yang ada pada restoran Al-Jazeerah untuk menemukan dimensi teritori personal yang ideal optimal agar pengunjung dapat melakukan aktivitas di area meja makan dengan efektif. Perbandingan berupa penguraian pada tabel sebagai berikut:

Tabel 2. Cakupan Dimesi Meja Makan Restoran Al-Jazeerah

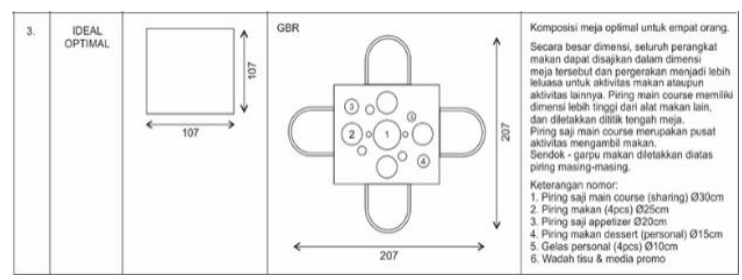


Erlana Adli Wismoyo, Ummu Havizahra: Pengaruh Dimensi Furnitur Terhadap Teritori

Personal Pengaturan Meja Makan dengan Sistem Makan Berbagi pada Restoran

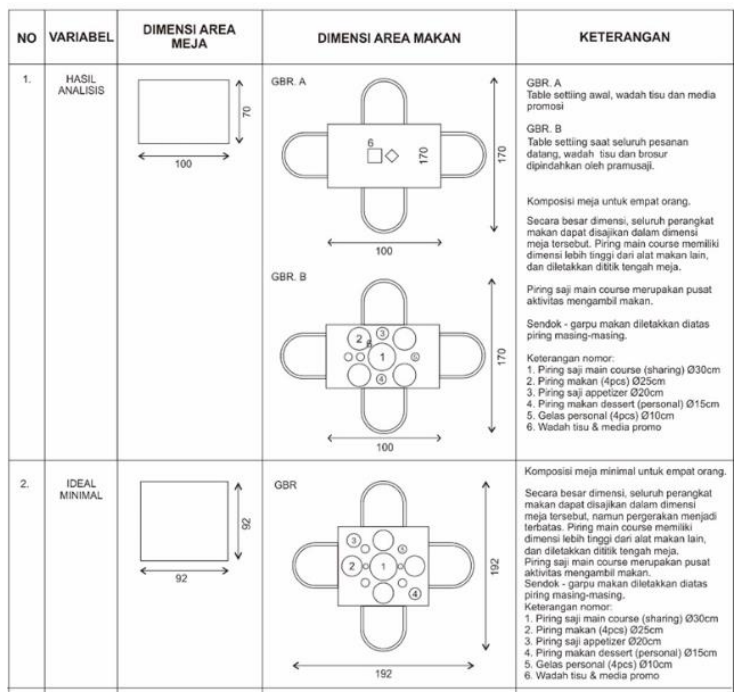

Dari uraian analisa ketika observasi langsung, simulasi makan dan tabel

Perbandingan terhadap restoran AlJazeerah, didapat bahwa:

1. Saat pola duduk bersebelahan, kebutuhan teritori personal yang ada di restoran Al-Jazeerah belum terpenuhi dengan cakupan dimensi 35 x $50 \mathrm{~cm}$ karena siku saling bersenggolan dengan orang yang bersebelahan.

2. Saat pola duduk diubah dan membentuk pola (+) plus, kebutuhan teritori personal yang ada di restoran Al-Jazeerah menjadi terpenuhi dengan cakupan dimensi 70 x 50 $\mathrm{cm}$ karena siku tidak lagi bersenggolan dan pengambilan hidangan yang lebih mudah.

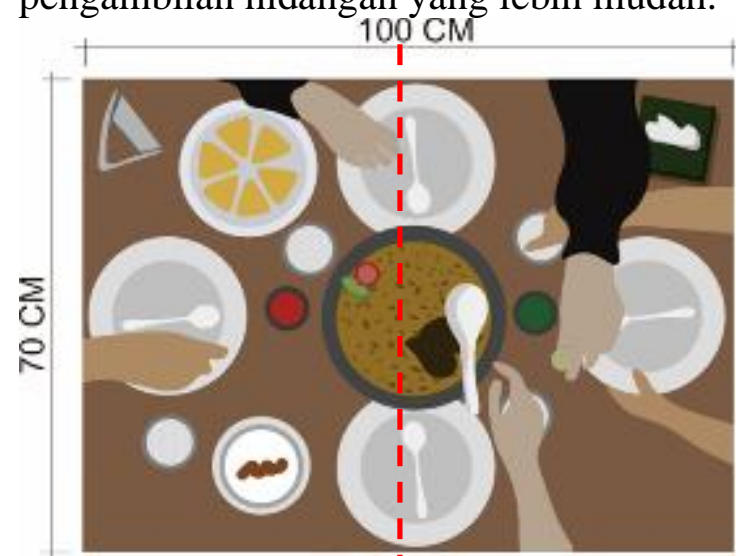

Gambar 17. Dimensi Meja Makan Sharing 4 Seater di Restoran Al-Jazeerah sumber : Olahan peneliti 2020

3. Setelah penyesuaian standar didapatkan teritori personal ideal optimal untuk restoran Al-Jazeerah dengan cakupan dimensi menjadi 53.5 x $53.5 \mathrm{~cm}$. Dengan begitu teritori personal ketika makan sharing dengan settingan makan tengah akan terpenuhi.

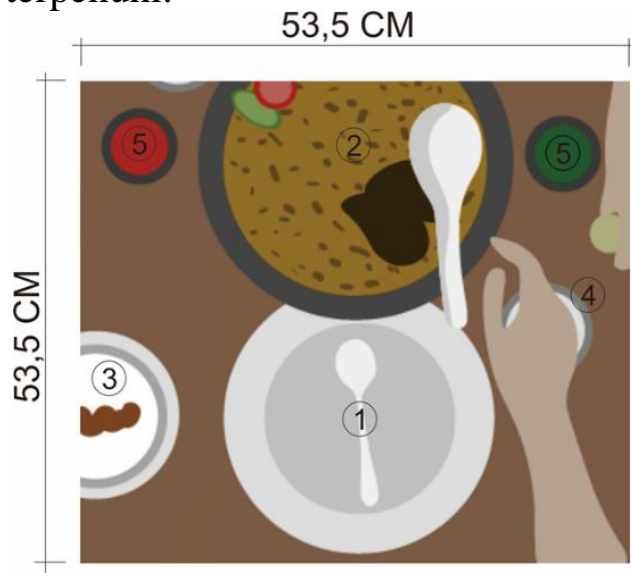

Keterangan Nomor :

1. Peralatan makan, 2. Hidangan utama : Lamb Kabsah, 3. Dessert: Umm Ali, 4. Minuman personal, 5. Sambal

Gambar 18. Ideal Optimal Teritori Personal Area Meja Makan untuk Restoran Al-Jazeerah sumber : Olahan peneliti 2020.

4. Setelah penyesuaian pola seater area teritori personal terlihat lebih luas untuk melakukan pergerakan ketika aktivitas makan-minum yang dilakukan dengan sistem sharing ruang gerak ketika aktivitas makan-minum dapat dilakukan dengan baik tanpa rasa tidak nyaman akan area yang sempit ataupun siku yang bersenggolan.

\section{b. Restoran Miss Bee Providore}

Restoran Miss Bee Providore berada di sebuah kawasan yang termasuk dataran tinggi di kota Bandung, tempat ini menawarkan sensasi wisata kuliner di kawasan yang terkenal memiliki pemandangan indah serta suhu udara yang cukup sejuk. Restoran ini juga terkenal akan suasana area makan outdoornya. Miss Bee Providore menerapkan sistem makan sharing dengan menu hidangan khas Western dan Asia. Restoran Miss Bee Providore ini memiliki konsep family dining, dimana memang sasaran konsumennya adalah rombongan keluarga ataupun orang-orang yang berkelompok. 
Erlana Adli Wiswoyo, Ummu Havizahra: Pengaruh Dimensi Furnitur Terhadap Teritori Personal Pengaturan Meja Makan dengan Sistem Berbagi pada Restoran

\section{Meja Makan}

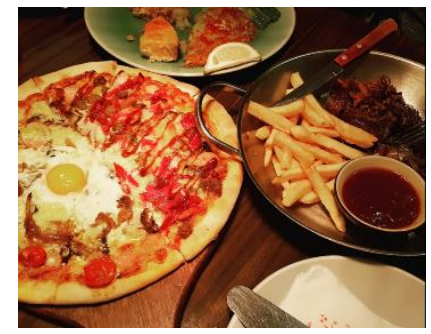

Gambar 19. Contoh Penataan Settingan Makan Tengah Hidangan Sharing (Miss Bee Providore) sumber : Google image 2018

Observasi langsung dilakukan dengan memesan hidangan lengkap (Main Course, Appetizer, Dessert, dan Beverage) yang merupakan sharing item dari restoran Miss Bee Providore. Observasi dilakukan oleh dua orang, namun karena penuh, peneliti duduk pada meja makan empat seater berbentuk persegi panjang yang berdimensi 160 x $59 \mathrm{~cm}$. Penyajian makanan dan minuman dihidangkan secara bersamaan dengan hidangan utama sharing diletakan pada bagian tengah meja makan.

\section{Table Setting}

Pada saat pengunjung datang, peralatan makan/cutleries belum disediakan.
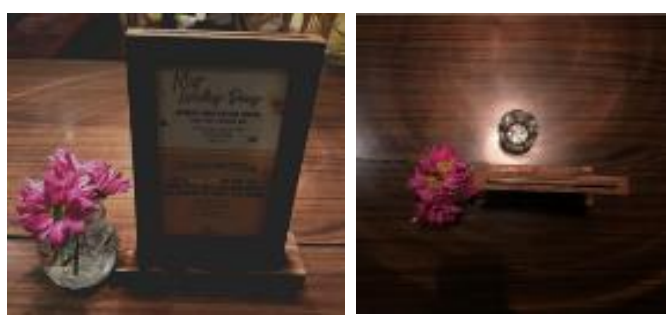

Gambar 20. Table Tent dan Vas Bunga Sumber: Dokumentasi peneliti 2020

Atribut meja yang ada di gambar 20 adalah table tent dan vas bunga kemudian barulah menu dan cutleries diberikan saat pengunjung duduk pada area yang sudah ditentukan. Penataan table setting pada restoran Miss Bee Providore adalah standart table setting.

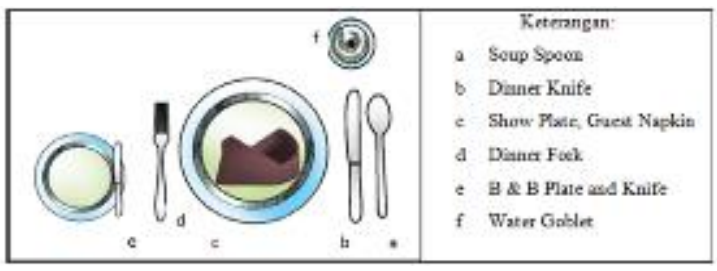

Gambar 21. Standart Table Setting

Sumber: Food \& Beverage and Table Setting

Standart table setting sendiri berarti table set-up yang digunakan untuk meja makan pagi (breakfast) dan makan siang dan malam (lunch and dinner).

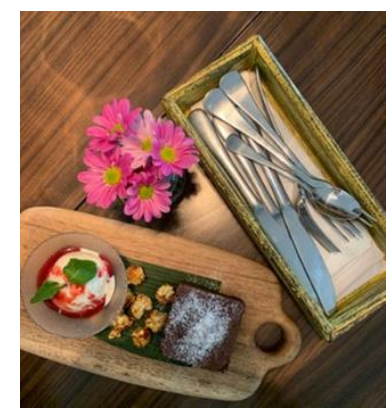

\section{Gambar 22. Peralatan Makan \\ Miss Bee Providore}

sumber: google image 2020

Standard table setting pada restoran Miss Bee Providore, yaitu dengan disediakannya piring, sendok, garpu, pisau makan, lap, dan nomor meja.

\section{Simulasi}

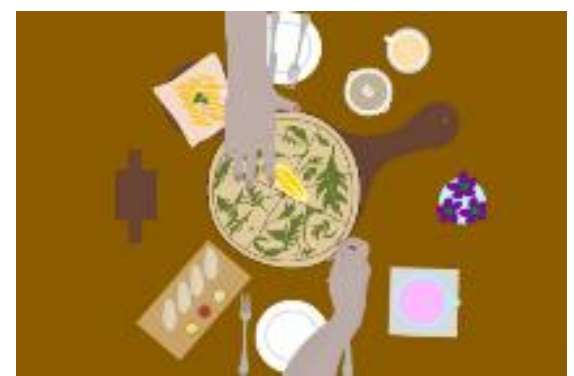

Gambar 23. Simulasi Settingan Makan Tengah Restoran Miss Bee Providore sumber : Ilustrasi peneliti 2020

Ketika survei Penyajian makanan dan minuman dihidangkan secara bersamaan dengan hidangan utama sharing berada ditengah kemudian disusun pada meja makan ukuran 160 x $59 \mathrm{~cm}$, dimana meja tersebut adalah meja makan untuk empat seater. 
Peneliti dan partisipan duduk secara berhadapan. Penyajian makanan dan minuman dihidangkan secara bersamaan dengan hidangan utama sharing berada ditengah meja.

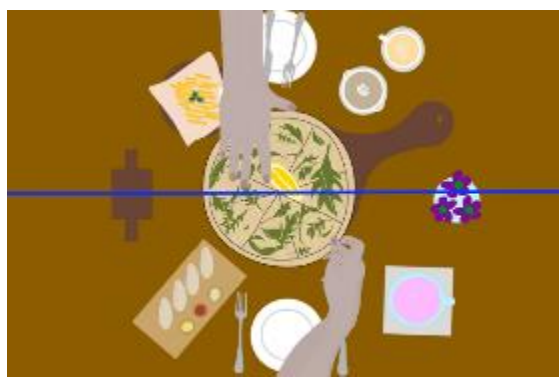

Gambar 24. Simulasi Pembagian Teritori Personal Area Makan pada Restoran Miss Bee Providore

sumber : Ilustrasi peneliti 2020

Dapat dilihat pada simulasi settingan makan diatas, hidangan utama diletakan di tengah meja makan.

Kemudian posisi pengambilan makanan per orang mengarah ke depan pada hidangan utama sharing. Yang terjadi ketika aktivitas makan-minum dilakukan :

1. Arah pengambilan makanan ke arah depan menuju pusat hidangan utama.
2. Pengambilan hidangan sharing dapat dilakukan secara bergantian maupun bersamaan, karena dimensi meja yang luas, hal ini memudahkan dalam pergerakan tangan ke berbagai arah.

3. Siku dapat menyanggah dibagian meja karena luasana samping kanan maupun kiri masih luas.

\section{Menu Hidangan Sharing}

Tabel berikut merupakan daftar beberapa menu hidangan sharing yang ada pada restoran Miss Bee Providore dan menjadi dasar untuk menganalisa teritori personal ketika penataan meja makan dengan pusat hidangan berada di tengah.

Berdasarkan pemesanan ketika observasi, terdapat 5 menu yang dipesan pada restoran Miss Bee Providore yaitu:

3 menu hidangan sharing (French Fries, Taco, Pizza), 2 hidangan personal (Soup, Vanilla Ice Cream), dan 2 minuman personal (Smoothies, Coffee).

Dapat dilihat restoran Miss Bee Providore juga memiliki hidangan sharing pada menunya. Hal ini membuat penyajian hidangan menjadi settingan makan tengah.

\section{Tabel 3. Menu Hidangan Sharing pada Restoran Miss Bee Providore}

\begin{tabular}{|c|c|c|c|c|}
\hline No & Nama Menu & Dimensi & Dokumentasi & Analisa \\
\hline 1. & $\begin{array}{c}\text { French Fries } \\
\text { (Appetizer) }\end{array}$ & $\varnothing 19 \mathrm{~cm}$ & & $\begin{array}{l}\text { Disajikan dengan pelengkap berupa chesee sauce. } \\
\text { Dapat diletakan disebelah hidangan utama sehingga } \\
\text { dapat menjadi hidangan sharing pelengkap, area yang } \\
\text { terpakai tidak besar. }\end{array}$ \\
\hline 2. & $\begin{array}{c}\text { Taco } \\
\text { (sharing item) }\end{array}$ & $\varnothing 26 \mathrm{~cm}$ & & $\begin{array}{l}\text { Disajikan terpisah dengan isian taco. Plating yang } \\
\text { digunakan berupa tatakan kayu dengan ukuran } \\
\text { lumayan besar. Area yang terpakai masih dapat } \\
\text { membuat efektif sirkulasi di meja. }\end{array}$ \\
\hline 3. & Soup & $\varnothing 12,5 \mathrm{~cm}$ & & $\begin{array}{l}\text { Dihidangkan dengan dua potong roti bawang/garlic } \\
\text { bread sebagai pelengkap. Area yang terpakai tidak } \\
\text { besar, masih dapat membuat efektif sirkulasi di meja, } \\
\text { soup masih dapat diletakan bersebelahan dengan main } \\
\text { course jika menu hidangan secara bersamaan. }\end{array}$ \\
\hline 4. & $\begin{array}{l}\text { Pizza }(\text { Main } \\
\text { Course- Sharing } \\
\quad \text { Item) }\end{array}$ & $\varnothing 30 \mathrm{~cm}$ & & $\begin{array}{l}\text { Dihidangkan dengan pelengkap saos sambal. ukuran } \\
\text { yang dipesan adalah medium size area yang terpakai } \\
\text { hanya bagian tengah meja, area kosong yang tersisa di } \\
\text { meja masih banyak, bisa dibilang efektif. }\end{array}$ \\
\hline
\end{tabular}


Erlana Adli Wiswoyo, Ummu Havizahra: Pengaruh Dimensi Furnitur Terhadap Teritori Personal Pengaturan Meja Makan dengan Sistem Berbagi pada Restoran

$\begin{array}{cc}\text { Jar : } \\ \text { 5. } \begin{array}{c}\text { Vanilla Ice } \\ \text { Cream (Dessert) }\end{array} & \varnothing 15 \mathrm{~cm} \\ & \text { Tatakan : } \\ & 22 \times 22 \mathrm{~cm}\end{array}$

Penyajian dessert dilengkapi dengan sendok khusus untuk memakan dessert tersebut. Area yang terpakai tidak besar, masih dapat membuat efektif sirkulasi dimeja.

6. $\begin{gathered}\text { Smoothies } \\ \text { (Minuman 1) }\end{gathered} \quad \varnothing 8,5 \mathrm{~cm}$

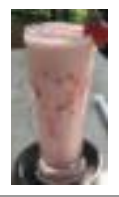

Penyajian smoothies dialasi dengan tatakan gelas, dapat diletakkan pada area yang tersisa setelah penempatan hidangan utama dan alat makan.

7. Minuman $2 \quad \varnothing 7 \mathrm{~cm}$

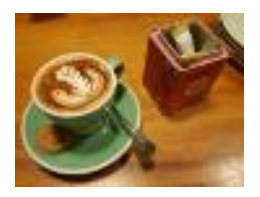

Penyajian minuman dengan sendok kecil dan diberi gula sachet dua bungkus untuk dituangkan sesuai selera konsumen. Minuman dapat diletakan pada area yang kosong yang tersisa karena ukuran cukup kecil.

Sumber : Olahan peneliti 2020

\section{Hasil Analisis}

Setelah dilakukan tinjauan dimensi standar teritori personal meja makan untuk dua seater dari buku Human Dimension dan buku Data Arsitek serta simulasi terhadap meja makan yang ada pada restoran Miss Bee Providore. Peneliti mencoba membandingkan hasil analisis dengan standar tersebut untuk menemukan dimensi optimal untuk teritori personal. Perbandingan berupa penguraian pada tabel 4.

\section{Tabel 4. Cakupan dimensi meja makan restoran Miss Bee Providore}

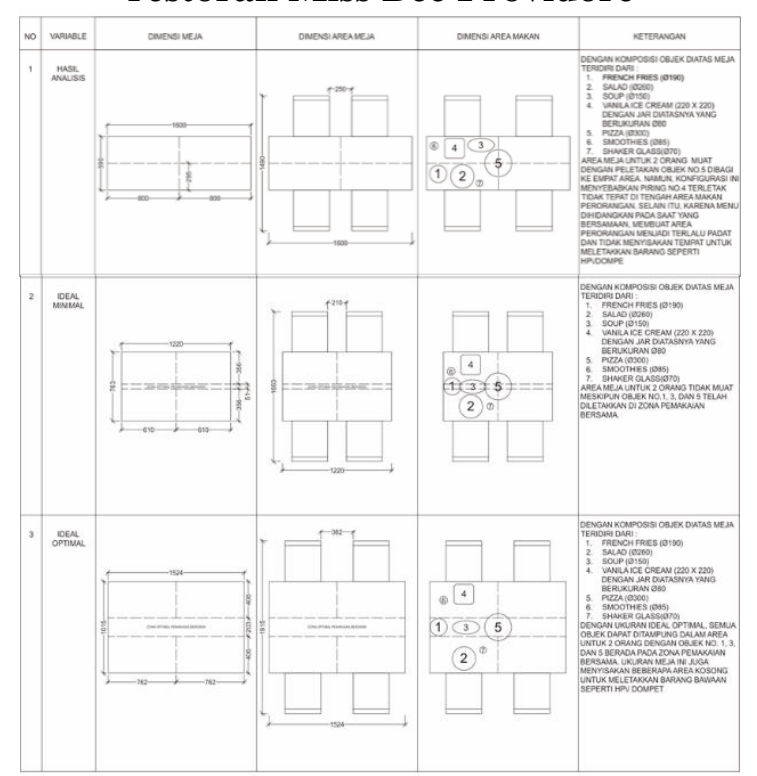

Sumber : Olahan data peneliti 2020
Dari uraian analisa, simulasi makan dan tabel perbandingan terhadap restoran Miss Bee Providore, didapat bahwa :

1. Kebutuhan teritori personal yang ada di restoran Miss Bee Providore terpenuhi dengan cakupan dimensi 29.5 x $80 \mathrm{~cm}$.

2. Didapatkan teritori personal ideal optimal untuk restoran Miss Bee Providore dengan penyesuaian standar dengan cakupan dimensi menjadi 40.2 x $76.2 \mathrm{~cm}$. Dengan begitu teritori personal ketika makan sharing dengan settingan makan tengah sudah terpenuhi.

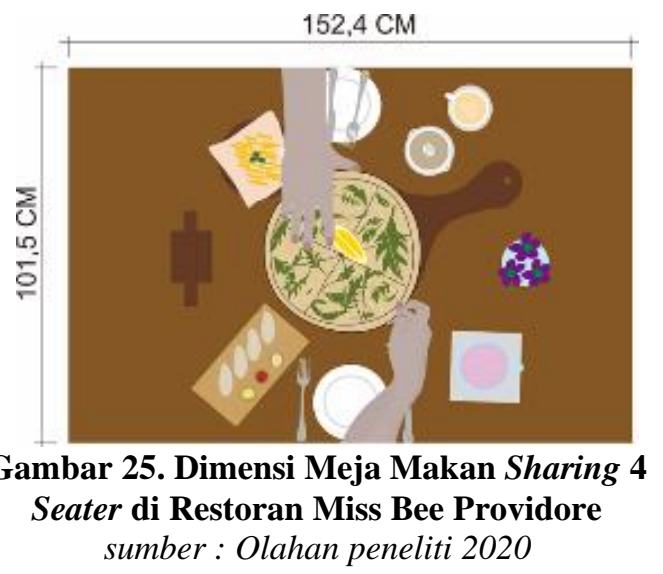

3. Penggambaran teritori personal area makan pada restoran Miss Bee Providore setelah dialkukan 


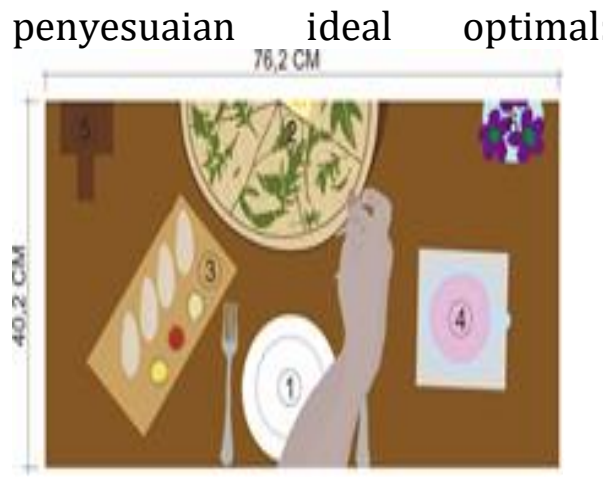

Keterangan Nomor :

1. Peralatan makan

2. Hidangan utama : Pizza

3. Appetizer : Taco

4. Dessert : Vanilla Ice Cream

5. Table Tent

6. Vas Bunga

Gambar 26. Ideal Optimal Teritori Personal Area Meja Makan untuk Restoran Miss Bee Providore sumber : Olahan peneliti 2020

4. Ruang gerak ketika aktivitas makanminum dapat dilakukan dengan baik tanpa rasa tidak nyaman akan area yang sempit ataupun siku yang bersenggolan.

\section{KESIMPULAN}

Area makan menjadi hal paling utama pada suatu restoran yang menentukan pengalaman ruang bagi penggunanya, untuk itu kenyamanan ketika aktivitas di meja makan perlu diperhatikan. Area makan itu sendiri terdiri atas meja makan, kursi, dan peralatan makan, beserta hidangan yang disediakan oleh restoran tersebut. Fasilitas meja makan haruslah sesuai dengan dimensi peralatan makan dari menu hidangan yang disediakan pada restoran dan memenuhi kebutuhan teritori personal yang berpedoman pada standar.

Menurut buku Human Dimension standar dimensi meja makan untuk memenuhi teritori personal pengunjung minimumnya adalah $60-76 \mathrm{~cm}$ sedangkan menurut buku Data Arsitek minimumnya adalah $\pm 61 \mathrm{~cm}$.

Standar-standar yang telah ditetapkan tersebut belum tentu dapat memenuhi kebutuhan teritori personal pada suatu restoran karena diperlukan penyesuaian terhadap dimensi cutleries/peralatan makan yang digunakan dalam penyajian menu hidangan.

Berdasarkan hasil dan pembahasan tentang teritori personal meja makan yang digunakan untuk hidangan sharing atau settingan makan tengah pada restoran AlJazeerah dan restoran Miss Bee Providore, diketahui bahwa pada restoran Al-Jazeerah kebutuhan teritori personal dapat terpenuhi dengan dimensi $53.5 \times 53.5 \mathrm{~cm}$ sedangkan pada restoran Miss Bee Providore kebutuhan teritori personal terpenuhi dengan dimensi 40.2 x $76.2 \mathrm{~cm}$. Maka dapat disimpulkan bahwa kebutuhan teritori personal pada suatu restoran dapat berbeda tergantung bentuk dan ukuran peralatan makan dari menu hidangan yang disediakan. Hal tersebut mempengaruhi dan menjadi dasar untuk menentukan dimensi meja makan yang akan digunakan pada area makan di suatu restoran.

\section{DAFTAR PUSTAKA}

Capatti, A., Montanari, M., \& O'Healy, A. (2003). Italian Cuisine: A Cultural History (Arts and Traditions of the Table: Perspectives on Culinary History) (Illustrated ed.). Columbia University Press.

Halim, D. (2005). Psikologi Arsitektur. Pengantar Kajian Lintas Disiplin. Jakarta: PT Grasindo. http://library.um.ac.id/freecontents/index.php/buku/detail/psiko logi-arsitektur-pengantar-kajianlintas-disiplin-deddy-halim31200.html

Hall, E. T. (1990). The Hidden Dimension (Anchor Books a Doubleday Anchor Book) (First Paperback Edition). Anchor. 
Erlana Adli Wismoyo, Ummu Havizahra: Pengaruh Dimensi Furnitur Terhadap Teritori Personal Pengaturan Meja Makan dengan Sistem Makan Berbagi pada Restoran

Heine, P., \& Lewis, P. (2018). The Culinary Crescent: A History of Middle Eastern Cuisine (Translation ed.). Gingko Library.

Hidayat, D. W., \& Setiawan, A. P. (2015). Perancangan Interior Cafe dan Restoran Khas Surabaya di Jalan Embong Malang Surabaya. Intra, 3(2), 92-101.

Hutama, C.L. \& Subagio, Hartono. (2014). Analisa Pengaruh Dining Experience Terhadap Behavioral Intention Dengan Customer Satisfaction Sebagai Variabel Intervening (Studi Kasus: Domicile Kitchen and Lounge). Jurnal Manajemen Pemasaran Petra. Vol.2. https://media.neliti.com/media/public ations/134793-ID-analisa-pengaruhdining-experience-terha.pdf

Ishak, M.T. \& Taufik, Y.R.T. (2018). Penataan Elemen Interior dan Perilaku Pengunjung Restoran sebagai Bentuk Penciptaan Teritori. Temu Ilmiah Ikatan Peneliti Lingkungan Binaan Indonesia (IPLBI), 7,C 057-062 https://doi.org/10.32315/ti.7.c057

Marsum (2005). A.W Marsum. 2005. Restoran dan Segala Permasalahannya. Edisi Empat. Yogyakarta: Andi.

Mulyono, M.A. (2001). Aktivitas Belajar. Bandung: Yrama

Neufert, E. (2019). Architects' Data (5th ed.). Wiley-Blackwell.

Nizar, F., \& Setyowati, E. (2021). PENGARUH PERILAKU PENGUNJUNG TERHADAP PERSONAL SPACE DI MASJID AL HADDAD PAMANUKAN PADA MASA PANDEMI COVID
19. Jurnal Arsitektur ARCADE, 5(1), 82-91.

Nur'aini, Ratna D. \& Ikaputra (2019). Teritorialitas Dalam Tinjauan Ilmu Arsitektur. Yogyakarta: INERSIA. https://journal.uny.ac.id/index.php/in ersia/article/view/24860.

Panero, J., \& Zelnik, M. (1979a). Human Dimension \& Interior Space: A Source Book of Design Reference Standards (Revised ed.). WatsonGuptill.

Rahayu, R. R., Setiyorini, H. D., \& Ryana, H. PENGARUH MEAL EXPERIENCE TERHADAP KEPUASAN PELANGGAN DI D'RIAM RIVERSIDE RESORT AND RESTO. Gastronomy Tourism Journal, 2(2), 172-179.

Sari, S. M. (2009). Komparasi Unsur Feng Shui Aliran Bentuk dan Ilmu Desain Interior pada Restoran Dapur Babah Elite di Jakarta. Dimensi Interior, $7(1), 1-15$.

Suyono, Joko. (2004). Food Service Management Dasar-Dasar Mengolah Bisnis Restoran. Bandung. ENHAII PRESS.

Wardiyanta, W., Septiyani, R., \& Rejeki, M. E. S. (2020). STUDI KASUS KUALITATIF KEBERHASILAN RESTORAN NON WARALABA DI YOGYAKARTA. Jurnal Inovasi Penelitian, 1(7), 1475-1486.

Yahya, Y. K. (2019). Pengaruh Penyebaran Islam di Timur Tengah dan Afrika Utara: Studi Geobudaya dan Geopolitik. Al-Tsaqafa: Jurnal Ilmiah Peradaban Islam, 16(1), 4462. 